\title{
Age Management in Danish Companies: What, How, and How Much?
}

I Per H. Jensen

Professor, Centre for Comparative Welfare Studies (CCWS), Aalborg University, Denmark ${ }^{1}$

\section{Rasmus Juul Møberg}

Assistant Professor, Centre for Comparative Welfare Studies (CCWS), Aalborg University, Denmark

\begin{abstract}
This article investigates Danish employers' behavior in the area of active aging, which is made topical by demographic aging. It describes age management practices and explains why some companies are more prone to employ age management than others. The study is based on a survey conducted among a representative sample of Danish employers, and 609 interviews in total have been carried out. Data have been scrutinized using frequency analysis for descriptive purposes as well as binary logistic regression analysis for explanatory purposes. Findings indicate that structural, cognitive, and action-oriented variables have significance for whether companies develop and employ active age management policies.
\end{abstract}

\section{KEYWORDS}

Aging workforce / active aging / age management / employers / extending working life / active aging friendly companies / demographic challenges / Denmark

\section{Introduction}

iscourses about demographic aging have made topical the enlargement-or rather, measures designed to combat the shrinking-of the labor force and extending the working life of older workers. This issue has been a high priority on the political agenda, and comprehensive research has provided input to the political system. The vast majority of this research has centered around the seniors (i.e., the individual), as attempt has been made at identifying what motivates seniors to exit the labor market. A prevailing understanding in this research has been that seniors are motivated or can be lured to exit the labor market by generous early retirement schemes (e.g., Blöndal and Scarpetta 1999; Börsch-Supan 2000; Gruber and Wise 1999), and a comprehensive wave of reforms in Europe has been inspired by this fundamental understanding (cf. Ebbinghaus 2006, 2011; Hofäcker 2010; Immergut et al. 2007; Palier 2010). On the political level, attempt has been made to keep more seniors in the labor market by dismantling or hollowing out early retirement opportunities.

\footnotetext{
${ }^{1}$ Per H. Jensen, Aalborg University, Fibigerstræde 1, 9220 Aalborg, Denmark.

E-mail: perh@dps.aau.dk
} 
The role and significance of the employers in terms of keeping more seniors in the labor market has been relatively neglected as an area of research, even though very persuasive arguments have been made that you cannot ignore what employers are (not) doing if a greater number of older wage earners are to be kept in the labor market (e.g., van Dalen et al. 2006; Hartlapp and Schmid 2008; Ilmarinen 2005; Vickerstaff et al. 2003). Research focusing on the employers has particularly focused on identifying strategies and examples of good practices, which can provide inspiration and guidelines for the companies that might be interested in investing effort in recruiting and hanging on to senior staff (cf. European Foundation 2006; Institute for Employment Research 2006; Walker 1997, 1999; Walker \& Taylor 1998). So far, however, there has been a considerable lack of conclusive evidence as to the extent to which age management as an overall vision or idea at the company level has been translated into concrete planning and action.

The purpose of this article is to cast light on the formation and dissemination of age management practices at the corporate level. Age management may be defined as measures that combat age barriers and/or promote age diversity (Walker 1999; 2002). Age management does not target seniors, as policies targeting specific age groups can be counterproductive. Younger employers will find affirmative action toward senior staff to be unjust, and they will react negatively if given a greater workload; moreover, the seniors themselves will find that they are labeled, pigeon-holed, and stigmatized (Friis et al. 2008). In a broad sense, age management is therefore about the efforts to maintain employability and workability over the entire course of life, and major age management instruments include job recruiting (and exit); training, development, and promotion; flexible working practices; and ergonomics and job design (Walker 1997, 1998, 2005; Walker and Taylor 1999). Basically, age management represents sound human resource management (HRM), without which companies could not recruit or retain their senior (i.e., older) personnel and without which older workers would not be able to participate in working life for as long as they wish to do so.

This article is structured around three interconnected themes. First, it surveys how employers cognitively perceive of older workers and the aging of the population in general as it is presumed that employers' cognitive perceptions set conditions for their inclination to act in an age management-appropriate manner. Second, it focuses on the extent and dissemination of which corporate age management policies the employers actually use. Third, our aim is to produce an explanation of why some companies make use of age management practices while others do not, while at the same time identifying which type of companies are most prone to employ such practices. In this empirical investigation, we make use of the employers' cognitive perceptions about seniors and aging as an explanatory variable. But we will also include more objective and structural variables, such as the size of the companies, the profile of the staff, which sector the company belongs to, as well as action-oriented variables such as whether a company has a written or unwritten senior policy. Finally, the article is rounded off by a brief summary of the central points.

The article is based on Danish experience and Danish data. Denmark has been chosen because discourses about active aging in employment have deep historical roots in the country (Jensen 2004). Referring to the demographic challenges, the Confederation of Danish Employers (DA) launched a campaign in the late 1980s, encouraging employers to carry out age management initiatives, and since the mid-to-late 1990s 
until the present, the Ministry of Employment has been engaged in massive information campaigns aimed at motivating employers to recruit older workers and keep them in the labor force. There is therefore reason to expect age management to be a rather mature phenomenon in Denmark, making Denmark a case worth analyzing.

Still, a supply-side oriented discourse has gained prominence in Denmark in recent years. Major reforms in the early retirement scheme have been carried out in 1998, 2006, and 2011, all with the aim of increasing older workers' employment rates. These reforms, however, have not been accompanied by more demands toward employers with regard to active aging. The employment protection of older workers remains extremely low in Denmark as compared with the other two Scandinavian countries (Jensen and Andersen 2011). Active aging is solely a responsibility of the individual company or of collective agreements. No tripartite institution like the Norwegian "Inclusive working life agreement" stimulating active aging exists in Denmark.

\section{Data}

The empirical data referred to in the article are based on a survey among Danish employers. The survey was conducted by Capacent A/S, a Danish company, and the survey was carried out in connection with the ASPA project, a project financed by the EU's Seventh Framework Programme (www.aspa-eu.com), in which older workers were defined as workers 50+ years of age. In the period April-June 2009, a gross sample of 2,912 CEOs, owners, and HR department managers in Danish companies with 10 or more employees were invited to participate in the survey, of which 609 completed the survey. About $95 \%$ of these companies had one or more older workers as employee(s).

The sample was stratified in terms of size and sectors in order to cover the different sectors and sizes of the companies. The results presented in the article are therefore weighted in relation to this stratification in the collection method.

The survey was conducted as an Internet survey. When potential respondents were approached, they were given a unique user name and password for use when logging into the Internet-based questionnaire. If the questionnaire was not responded to, the company was contacted by phone with further encouragement to participate in the survey. The company was contacted up to ten times before giving up on them.

The response rate was approximately $28 \%$. This is a relatively low response rate compared with individual surveys but rather high in a corporate survey perspective, where response rates have been found to be at most 20-30\% (Brewster et al. 1994; Kalleberg et al. 1996). Among the non-respondents, nearly 300 respondents terminated the Internet questionnaire without completing it. Naturally, the incomplete questionnaires are not included in the dataset used in this article. However, information retrieved from these partially completed questionnaires can help shed light on possible sample selection biases. It is therefore possible to hypothesize that the companies that have employed senior staff and are preoccupied with age management challenges will be more inclined to complete a questionnaire about the aging workforce than employers who do not have older employees. However, evidence (not presented here) for such a self-selection could not be ascertained through comparison of the fully and partially completed questionnaires. No difference in response pattern between the fully and the 
partially completed questionnaires could be observed, a fact that may be an indication of the validity of the data.

\section{Employers' cognitive perceptions}

This section, which addresses the cognitive perceptions held by employers regarding age and aging, analyzes two factors, which must be assumed to have significance for how employers act vis-à-vis their senior staff. First, we will investigate whether there is a sense of urgency among employers regarding demographic challenges. We will therefore identify whether the employers have accepted and subscribed to the discourse about population aging; whether they are of the opinion that something ought to be done in this regard-and if so, what they feel should be done in order to meet the challenge. Next, we will survey how the employers perceive the differences between younger and older employees, that is, whether they regard seniors as equally attractive and productive labor as younger personnel. This can have significance for the opportunities available to seniors to remain in the labor market, as the employers are unlikely to be satisfied with employing or hanging on to their senior staff if they regard them as inferior personnel.

\section{The view of employers on the demographic development}

DA articulated early on how the demographic aging of the population represents one of the greatest challenges facing the Danish welfare state. However, the question is whether this idea has resonated with the individual employer, that is, whether the sense of reality on the macro level corresponds with the sense of reality at the micro level (the individual company). This is not always the case. For example, van Dalen et al. (2006) carried out a comparative study in which they found a discrepancy between macrounderstandings, micro-understandings, and practices related to senior policy; however, this does not appear to be the case in Denmark. More than seven out of ten Danish companies $(72.9 \%)$ thus indicate that it is "likely" $(57 \%)$ or "very likely" $(15.9 \%)$ that the aging of the population can possibly create problems in the labor market in the future. In other words, the individual employers appear to perceive the demographic development in a manner that is in accordance with the view articulated at the macro level by DA.

Many Danish employers seem to have internalized the sense of reality expressed by DA, but the individual employer is not necessarily in line with the employers' association when it comes to how to respond to the prospects for a reduced labor supply. While DA advocated an age management strategy toward the end of the 1980s, the organization subsequently adopted the incentive discourse in the late 1990s. The incentive discourse includes the notion that generous welfare schemes lure seniors away from the labor market, for which reason the dismantling or hollowing out of retirement opportunities automatically will contribute to keeping more seniors in the labor market, and this idea has also come to dominate the public discourse in Denmark.

Whether this has also had an impact on how the individual employers perceive the world around them will be presented in Table 1, which illustrates how the individual employers believe the aging of the population ought to be dealt with and which 
Table I Employers' views on which instruments should be employed in order to deal with a shrinking labor force.

\begin{tabular}{lcccccr}
\hline & $\begin{array}{c}\text { Strongly } \\
\text { against (\%) }\end{array}$ & $\begin{array}{c}\text { Against } \\
(\%)\end{array}$ & $\begin{array}{c}\text { Neutral } \\
(\%)\end{array}$ & $\begin{array}{c}\text { In favor } \\
(\%)\end{array}$ & $\begin{array}{r}\text { Strongly in } \\
\text { favor (\%) }\end{array}$ & $\begin{array}{r}\text { PDI } \\
\text { value }\end{array}$ \\
\hline Raising the legal retirement age & 3.6 & 26.2 & 34.6 & 31.9 & 3.7 & 5.8 \\
\hline $\begin{array}{l}\text { Encouraging people to have more } \\
\text { children }\end{array}$ & 2.5 & 9.8 & 45.9 & 37.7 & 4.1 & 29.5 \\
\hline Attracting foreign workers & 2.3 & 7.8 & 30.9 & 54.6 & 4.3 & 48.8 \\
\hline $\begin{array}{l}\text { Encouraging part-time workers to } \\
\text { change to full-time work }\end{array}$ & 0.3 & 6.8 & 23.9 & 61.6 & 7.5 & 62.0 \\
\hline $\begin{array}{l}\text { Cutting back early retirement programs } \\
\text { Increasing the number of legal weekly }\end{array}$ & 5.0 & 36.8 & 34.3 & 22.6 & 1.3 & -17.9 \\
\hline \begin{tabular}{l} 
working hours \\
\hline
\end{tabular} & 39.6 & 32.3 & 21.1 & 0.9 & -23.7 \\
\hline
\end{tabular}

Question: "How should Denmark deal with the prospect of a shrinking labor force?" $N=604$.

Note: The PDI value indicates the "in favor" responses (in favor, strongly in favor) minus the "against" responses (strongly against, against). The middle category, "neutral," is not included. A positive PDI therefore means that there is a majority for the statement presented in the question, whereas a negative figure indicates that the majority is against the statement in question.

Source: ASPA.

instruments ought to be applied in this respect, that is, whether efforts to combat the shrinking of the labor force ought to include a higher age of retirement, encourage people to have more children, and so on.

Given that DA has advocated the incentive discourse for many years and given that this discourse has dominated the political debate in Denmark, the most surprising detail in Table 1 is that most Danish employers are not of the opinion that the efforts to deal with the aging of the population should include abolishing the opportunities for early retirement. Only $1.3 \%$ are "strongly in favor," and $22.6 \%$ are "in favor" of "cutting back early retirement programs." Moreover, the table shows how only a slight majority of Danish employers believe that the age of retirement should be increased. This signals a clear discrepancy between the macro (DA) and micro (individual employers) levels in terms of how the demographic challenges are to be met. This discrepancy possibly owes to the fact that while the individual employer presumably knows where the shoe pinches in their everyday work-they know their employees and their respective breaking points-DA's positions are based far more on principle and theory.

The most preferred options among Danish employers in relation to the shrinking labor force are encouraging people to have more children, attracting foreign workers (which at present is not a politically feasible option in Denmark), and encouraging parttime workers to work full time, while Danish employers are not in favor of increasing the work week (i.e., the number of hours for full-time work) for their staff. Nevertheless, even though Danish employers and the employers' association prefer different options and solutions, the Danish companies and DA alike are aware of the problem regarding the aging of the population. However, it is possible that individual employers are not in favor of cutting back early retirement programs due to their negative perception of 
older workers, and that such negative perception may want them to get rid of senior employees by means of publicly funded early retirement schemes.

\section{Employers' perceptions of the differences between younger and older employees}

For employers to make an active effort with respect to recruiting and retaining senior staff, they must believe that their older personnel actually represent a resource worth investing in and retaining (see, e.g., Brooke 2003). Studies have shown, however, that many employers are biased or have prejudices in relation to seniors (see, e.g., Gringart et al. 2008; Henkens 2005). In as much as these prejudices become manifest in prejudicial treatment on the basis of age, there is talk of discrimination, which can assume the form of statistics-based (Aigner and Cain 1977; Correll et al. 2007; Dickinson and Oaxaca 2006) and status-based (Berger et al. 1972; Knottnerus and Greenstein 1981; Lee and Clemons 1985; Perry and Bourhis 1998; Perry et al. 1996, p. 630; Rosen and Jerdee 1976) discrimination. Discrimination is the antithesis of active aging, as age discrimination leads to the premature exclusion of older wage earners from employment (Walker 2006, p. 127). The employment prospects of older wage earners are therefore closely associated with the employer attitudes toward aging employees.

Many employer-targeted campaigns organized by the Ministry of Employment have attempted to fight negative biases or prejudices against older wage earners. In these campaigns, the Ministry has attempted to promote older employees in a positive light, that is, as attractive labor that the companies would benefit from keeping on or even recruiting. The majority of these campaigns are based on social-gerontological studies that find that both younger and older personnel have strengths and weaknesses. The seniors' strengths are their great life experience, stability, maturity, independence, and professionalism and that they radiate a sense of calm, perspective, and social understanding. Conversely, the older employees are slower at learning new things, are less flexible and physically weaker than younger employees, and anxious when it comes to the development of new skills and competencies (cf. e.g., Casey 2007; Friis et al. 2008; Griffiths 2007; Hansen and Jensen 2007; Jepsen 2002; Kirk 2007; Larsen 2006; Luccat 2005; Skirbekk 2003). This is hardly an exhaustive account of the strengths and weaknesses of older employees, just as it says little about a specific employee (Mrs Jane Doe) employed by Company Y. Nor can this account be used to carry out calculations that ultimately prove that the strengths of seniors outweigh their weaknesses-or vice versa. But it does say something about how older employees have different qualities than younger employees and that these qualities can be used actively and meaningfully in the workplace.

The question, however, is whether the employers have an eye for the qualitative advantages of seniors-what the older employees have to offer. Whether the employers view their senior personnel positively is of decisive significance, as this can have an impact on their inclination to recruit or retain senior personnel. Table 2 presents an overview of how the employers rate seniors and younger employees on different characteristics, including flexibility, social skills, loyalty, and productivity (see first column). Employers have thus been asked whether these characteristics, such as flexibility, apply to workers over age 50 (age $>50$ ), as well as the extent to which these characteristics 
Table 2 Employers' views on how different characteristics apply to younger and older employees. Differences between younger and older employees.

\begin{tabular}{lccccc}
\hline & Age & $\begin{array}{c}\text { Not at all/ } \\
\text { Low extent (\%) }\end{array}$ & $\begin{array}{c}\text { Some } \\
\text { extent }(\%)\end{array}$ & $\begin{array}{c}\text { High } \\
\text { extent (\%) }\end{array}$ & $\begin{array}{c}\text { Very high } \\
\text { extent (\%) }\end{array}$ \\
\hline Flexibility & $<35$ & 12 & 45 & 40 & 3 \\
& $>50$ & 10 & 46 & 40 & 4 \\
\hline Social skills & $<35$ & 17 & 59 & 22 & 2 \\
& $>50$ & 4 & 33 & 58 & 5 \\
\hline Loyalty & $<35$ & 43 & 44 & 12 & 1 \\
& $>50$ & 2 & 12 & 68 & 18 \\
\hline Productivity & $<35$ & 6 & 41 & 49 & 4 \\
& $>50$ & 7 & 53 & 37 & 3 \\
\hline Creativity & $<35$ & 3 & 23 & 63 & 5 \\
\hline Managerial skills & $>50$ & 28 & 55 & 16 & 1 \\
\hline Reliability & $>35$ & 30 & 55 & 15 & 0 \\
& $>35$ & 15 & 46 & 36 & 3 \\
\hline Willingness & $>50$ & 2 & 59 & 20 & 1 \\
to learn & $>35$ & 2 & 14 & 66 & 18 \\
\hline Physical health & $>50$ & 30 & 16 & 67 & 15 \\
and stamina & $>50$ & 6 & 53 & 17 & 3 \\
\hline Ability to cope & $<35$ & 19 & 30 & 66 & 8 \\
with stress & $>50$ & 19 & 59 & 14 & 3 \\
\hline New technological & $<35$ & 2 & 59 & 21 & 2 \\
skills & $>50$ & 53 & 47 & 32 & 3 \\
\hline Quesion: & 24 & 18 & 63 & 17 \\
\hline
\end{tabular}

Question: "To what extent do you think the following characteristics apply to workers aged 50 and older?" and "To what extent do you think the following characteristics apply to workers younger than age 35 ?" $N=593$.

Source: ASPA.

apply to workers younger than 35 (age <35) (see second column), and the respondents have been presented with four possible responses: "not at all/limited extent," "some extent," "high extent," and "very high extent" (see first row). As figures in columns three to six are percentages, figure 2 thus shows, for instance, that $12 \%$ of the respondents do "not at all" or to a "low extent" find persons younger than age 35 flexible, while $10 \%$ of the respondents do "not at all" or to a "low extent" find persons over age 50 flexible.

The findings in Table 2 regarding employers' views on the strengths and weaknesses of younger and older employees are highly in accordance with the social-gerontological insights mentioned above. Employers indicate that seniors outscore younger employees in characteristics such as social skills, loyalty, managerial skills, reliability, and the ability to cope with stress. If columns five and six (i.e., "high extent" and "very high extent") are added, Table 2 shows that $63 \%$ of all of the respondents find that seniors have high levels of social skills, while this only regards $24 \%$ of younger employees; $86 \%$ of all 
respondents find that seniors are highly loyal, whereas this only applies to $13 \%$ of the respondents when assessing younger employees; $39 \%$ of the respondents hold that seniors have high managerial skills, but only $15 \%$ of the respondents have the same view with respect to the younger employees; $84 \%$ of the respondents believe that seniors are highly reliable, whereas this is only the case for $21 \%$ of the respondents when rating younger employees; $35 \%$ of the respondents report that older workers are able to cope with stress to a high degree, while $23 \%$ of the respondents find that younger employees are able to cope with stress to a high degree. Thus, older personnel have many qualities as compared with younger staff, but the younger employees also have their advantages. Younger employees score highest on parameters such as productivity, creativity, willingness to learn, physical health, and stamina, as well as the ability to acquire new technological skills.

For some of these characteristics, the differences between younger and older employees are relatively limited, as is the case with how the employers evaluate the productivity of their younger and older employees. A total of $53 \%$ of all of the respondents find younger employees highly productive, whereas $40 \%$ of the respondents report that older employees are highly productive. Given the insights from social-gerontology mentioned above, e.g., older workers are expected to be less flexible than younger workers, it is somewhat surprising that employers do not feel as though there are differences between younger and older employees regarding the question about flexibility. While $43 \%$ of the respondents find younger employees highly flexible, $44 \%$ find older employees highly flexible. That is, the employers do not consider their senior personnel as less flexible than the younger employees.

Finnish social-gerontologist Ilmarinen (2005) has convincingly argued that human resources and capacities change over the course of life, which is also reflected in the employers' different views on their younger and older employees. But this also opens up for the optimization of the productivity of labor if taking the life phase-specific characteristics and qualities into account when planning jobs. As such, the retentive effect would be considerably strengthened if the jobs the seniors are to fill have a content corresponding to their strengths and characteristics. However, such measures aimed at retention require that the employers are willing in practice to form the jobs so that they match their senior personnel. In the following, we will therefore examine the extent and nature of the age management practiced by the employers.

\section{What do the employers actually do in practice?}

As already mentioned, $72.9 \%$ of the responding Danish companies regard the aging of the population and a shrinking workforce as possibly leading to problems in the labor market. In other words, there is widespread awareness among Danish employers regarding the aging problem. As becomes apparent in Table 3, however, relatively few companies have actually applied this knowledge in their corporate personnel policy. Table 3 thus shows the extent to which awareness of an aging population has been applied in practice, as it reports the degree to which the aging of the population has had an impact on companies' HRM policies.

Despite the fact that seven out of ten companies (72.9\%) regard the demographic development as a phenomenon that can possibly create labor market problems in the 
Table 3 The degree to which the aging of the labor force plays a role in the HRM policy (\%).

\begin{tabular}{lc}
\hline Not at all & 20.2 \\
\hline Fairly low extent & 32.7 \\
\hline Some extent & 40.7 \\
\hline High extent & 6.3 \\
\hline
\end{tabular}

Question: "To what extent is the aging of your workforce an issue in your human resource management?" $N=607$.

Source: ASPA.

future, only $47 \%$ of the Danish companies apply this insight to "some extent" $(40.7 \%)$ or to a "high extent" $(6.3 \%)$ in the company's personnel policy. Earlier studies also show how relatively few Danish employers have a written or unwritten policy for their older personnel. In 2005, the share of Danish employers belonging to this group was $45 \%$ (Larsen 2006; Larsen and Miiller 2006).

Table 4 Instruments applied by Danish companies in their age management policy.

\begin{tabular}{lcc}
\hline & Already used (\%) & Will be considered (\%) \\
\hline Part-time retirement & 8.8 & 23.6 \\
\hline Reduction of working time before retirement & 33.8 & 29.2 \\
\hline Training plans for older workers & 7.2 & 16.8 \\
\hline Early retirement schemes & 6.1 & 21.4 \\
\hline Possibilities of extra leave for older workers & 25.9 & 30.0 \\
\hline Decreasing the workload for older workers & 23.9 & 31.9 \\
\hline Reduction in task and salary (demotion) & 9.4 & 21.1 \\
\hline Ergonomic measures & 28.2 & 18.5 \\
\hline An age limit for irregular work/shift work & 5.7 & 8.4 \\
\hline Promoting internal job mobility & 19.7 & 19.5 \\
\hline Continuous career development & 27.2 & 21.2 \\
\hline Flexible working hours & 52.5 & 21.4 \\
\hline
\end{tabular}

Question: "Which of the following measures regarding older workers are currently applied in your establishment? If not, do you expect it to be considered in the near future?" $N=57$ I.

Source: ASPA.

It is one thing if the aging of the labor force plays a role in the company personnel and HRM policy, but which instruments companies use in their age management is something else. The first column in Table 4 shows which senior policy instruments are used by Danish companies, while the second column indicates the percentage of Danish companies actually using the instruments. Column 2 adds up to more than $100 \%$, because the companies have been able to indicate that they use more than 
one senior policy instrument at a time. For example, a company can possibly use both "flexible working hours" and "ergonomic measures." Finally, the third column provides information about which age management initiatives are under consideration in Danish companies. When something "will be considered," this covers everything from loose ideas to being far along in the planning stage. Column 3 also adds up to more than $100 \%$ for the same reasons as referred to in connection with the second column.

As can be seen from Table 4, which only includes companies with older employees, the most commonly applied personnel policy instruments are generally about the regulation of the working hours, as in the form of "flexible working hours" $(52.5 \%)$, "reduction of working time before retirement" $(33.8 \%)$, and more "possibilities for extra leave for older workers" $(25.9 \%)$. Efforts aimed at balancing job requirements and the seniors' resources are also widespread, as, for example, seen when the responsibilities of senior personnel are reduced, "promoting internal job mobility," continuous career development, and ergonomic measures. The questionnaire upon which Table 4 is based is not comparable with earlier Danish studies. However, it should be mentioned that studies carried out in 2005 (Larsen 2006; Larsen and Miiller 2006) also point out "less demanding work" and "reduced" and "more flexible working hours" as some of the very widespread senior policy instruments in companies with more than ten employees. The 2005 studies also found that "competence development/continued education" was the most widespread personnel policy instrument, as it was applied in $61 \%$ of the Danish companies in 2005 , and it is probably also one of the most important age management instruments, as a recent study has shown that training and education help older workers to prolong their labor market career (Møberg 2011). Conversely, only $7.2 \%$ of all Danish companies used "training plans for older workers" in 2009, while $27.2 \%$ applied "continuous career development" as a personnel policy instrument in the same year. In total, this leaves the impression of a fall in the continued education activities in Danish companies in the wake of the financial crisis.

The fall in the education activities since the advent of the financial crisis is presumably a brief drop in the level of activity. As indicated in Table 4 (third column), 21.2\% of the Danish companies report that they are considering the use of "continuous career development," while $16.8 \%$ report that "training plans for older workers" are being considered. At the preparatory stage, however, "decreasing the workload for older workers" is the most common age management policy.

\section{Which companies have active senior policy?}

This section will analyze more specifically which types of companies work actively to keep their older employees in the labor market, and two of the questions in our corporate survey are intended for this purpose. We have asked the companies the following question: "To what extent is the aging of your workforce an issue in your human resource management?" As already mentioned, 47\% of the Danish companies confirm that this is the case to "some" or to a "high" extent. As Oxford Research (2005) and others have pointed out, however, just because a company has a written or unwritten senior policy does not necessarily mean that it is also used; in other words, the existence of a policy does not guarantee genuine action, as senior policies may remain "dead words." We have therefore chosen to use a second question in our survey of Danish companies 
Table 5 Share of Danish companies with an active age management policy (\%).

\begin{tabular}{lc}
\hline Never & 71.5 \\
\hline Occasionally & 25.9 \\
\hline Often & 2.7 \\
\hline
\end{tabular}

Question: "In the last two years, how often did you ask older workers to delay their date of retirement by one or more years?" $N=548$.

Source: ASPA.

to cast light on whether companies are actually doing anything in practice to retain their senior personnel. To illuminate age management in practice, we will take our point of departure in the following question: "In the last two years, how often did you ask older workers to delay their date of retirement by one or more years?" As already mentioned, this question has been posed to a representative sample of Danish companies, and responses from Danish companies to this question are presented in Table 5, which only includes companies with older employees.

The table shows the extent to which Danish companies are actually doing something with respect to senior policy, and as the table indicates, $71.5 \%$ of the Danish companies have "never" asked an older employee to wait with retirement for one or more years in the course of the last 2 years; $25.9 \%$ have done so "occasionally," and only $2.7 \%$ have done so "often." It is somewhat surprising that only $28.6 \%$ (i.e., the sum of those who have done so "occasionally" and "often") of Danish companies have actively done something to hang on to their senior personnel within the past 2 years, as $72.9 \%$ of the Danish companies find, as already mentioned, that the aging of the population will possibly create problems in the labor market in the future. The point is, however, that we believe that this question has enabled us to identify the companies that are genuinely active with respect to policy for older employees, and the following is aimed at arriving at a better understanding of what characterizes the companies with active senior policy.

Toward this end, the practice of Danish companies with respect to age management will serve as the dependent variable in a binary logistic regression analysis. In order to carry out a binary logistic regression, two response categories of the questions presented in Table 5 are summed together. This includes the response categories "occasionally" and "often." The dependent variable is subsequently dichotomous, where the value $0=$ "never" and 1 = "occasionally" and "often." The analysis will also include several groups of independent variables, that is, structural, cognitive and action-oriented variables. A total of seven independent variables are therefore included.

As to the structural independent variables, existing hypotheses seem to indicate that the sector, form of ownership-whether the enterprise is public or private- the number of employees, and the so-called knowledge intensity of the company have significance with respect to whether it will adopt senior policy measures (Casey 2007; Griffiths 2007; Larsen 2006; Larsen \& Miiller 2006; Martin 2004; Vickerstaff et al. 2007, p. 214). "Sector" and "number of employees in the company" are therefore included in the analysis, and so is the "percentage of unskilled employees," which will be used as a proxy for the knowledge intensity of the company. 
The hypothesis has already been presented in this article that cognitive and actionoriented variables can have significance for whether companies develop policy and practice aimed at older employees. Two cognitive dependent variables are included in the analysis: First, whether employers perceive that persons over age 50 show "willingness to learn," and second, the "percentage of employees over 50 in the company." The latter is expected to have a feedback effect on employers perception, that is, the more older employees in a company, the more the employer is expected to have an experience-based understanding of their older employees, just as one would expect companies with many older employees to be more inclined to apply age management as opposed to companies with few or no older employees. In relation to the employers' action orientation, two independent variables are also used. The first touches upon whether the company "has clear guidelines with respect to age management," that is, whether the company has a written or unwritten senior policy. It is expected that companies with an age management policy are more ready to use age management in practice than companies that have no such written or unwritten policy. The second is about whether the company experiences a sense of urgency regarding the demographic challenge, which is captured in the following question: "To what extent is the aging of your workforce an issue in your human resource management?" It is thus expected that companies that are preoccupied with demographic challenges are also more inclined to apply age management policies than companies that do not share the same concerns.

\section{Analysis}

The binary logistic regression analysis is presented in Table 6, and only companies with senior employees are included in the analysis. As can be seen, $17.3 \%$ of the variance in companies' responses to the question: "In the last two years, how often did you ask older workers to delay their date of retirement by one or more years?" can be explained by the included variables in the model.

Table 6 shows that the structural conditions have a certain significance for keeping older employees in the company. It becomes apparent that the companies in the production sectors are more active than the companies in other sectors with respect to retaining older employees, although the effect is only significant at the $10 \%$ level. This can be read out of how the odds ratio for the service sector and the public sector is around 0.63 for both sectors. If, we consider the size of the company measured in terms of the number of employees, however, a clearer pattern emerges.

Larger companies do more than smaller companies encourage their older employees to delay their exit from the labor market. The analysis reveals a four times lower odds ratio for a company with 10-49 employees to have encouraged a senior staff member to delay their retirement as compared with companies with more than 250 employees. This confirms past studies, which have also found that the size of the company has significance for activities aimed at retaining senior staff (see, e.g., Larsen 2006; Larsen and Miiller 2006). The sector a company belongs to and its size are, in other words, relevant when talking about retaining personnel, the size of the company being the most central variable in this context.

That larger companies are more inclined to develop an age management policy is often explained with reference to how larger companies have HRM departments and 
Table 6 Characteristics of companies with an active retention policy, binary logistic regression (odds ratio).

\begin{tabular}{lc}
\hline Sector & - \\
Production (baseline) & 0.64 \\
Service & 0.62 \\
Public & \\
\hline Number of employees in the company & $0.29 * * *$ \\
10-49 & $0.54 * *$ \\
$50-249$ & - \\
$250+$ (baseline) & 0.998 \\
\hline Percentage unskilled employees at the company & $1.02 *$ \\
\hline Percentage employees over 50 years at the company & $0.41^{*} *$ \\
\hline In this establishment we have clear guidelines with respect to age management & 0.64 \\
Completely disagree/disagree & - \\
\hline
\end{tabular}

\section{To what extent is the aging of your workforce an issue in your human resource management?}

Not/fairly low extent

Some extent/high extent (baseline)

\section{Persons over age $\mathbf{5 0}$ are willing to learn}

Not/low extent

Some extent (baseline)

High extent/very high extent

Note: Binary logistic regression (In the last 2 years, how often did you ask older workers to delay their date of retirement by one or more years? $(0=$ never, $1=$ occasionally and often $)$ ).

P-value: $* * *<0.001$; $* *$ * 0.01 ; $* 0.05$; italics $<0.1$.

Source: Unweighted ASPA data.

devote more resources to personnel development than smaller companies. Nevertheless, it is important to be cautious before drawing absolute conclusions. The picture can be affected by the fact that larger companies, ceteris paribus, have a greater probability than smaller companies to have more older employees and possibly therefore also a greater need to develop age management policies. We have therefore taken into account whether the share of employees over age 50 positively correlates with an active retention policy, which is actually the case. It is therefore possible to assume that an active age management policy is promoted to some degree by experience with older 
employees-understood as the greater the share of employees over age 50, the greater the knowledge of the employee group in question, and the greater the inclination to make age management an integrated aspect of personnel policy.

Another structural feature of companies that we have investigated is their knowledge intensity. We have thus applied the employees' qualification structure as a proxy for the knowledge intensity of companies, and it is expected that knowledge-intensive firms will be inclined to adopt age management policies. If such an effect should be found, the correlation between the share of unskilled employees and retention of senior employees should be negative. Table 6 , however, is unable to provide evidence of such a connection on the basis of the chosen indicators, as the correlation is insignificant. That is, it does not seem as though knowledge-intensive firms are more inclined to employ age management policies than other types of firms.

Table 6 also indicates that the action orientation among employers has significance for the age management practices. In the companies that do not have a written or verbal personnel policy-that is, where the respondents report that they "disagree" or "completely disagree" with the following statement: "In this establishment, we have clear guidelines with respect to age management," employers encourage to a far lesser extent seniors to delay their retirement from the labor market as compared with the companies that do have clear senior policy guidelines (odds ratio 0.41 ). In other words, it makes a difference to the retention of senior staff members whether or not a company has senior policy guidelines. Personnel policy is therefore not (always) only words on paper, as it is possible to trace a positive effect of having formulated a personnel policy.

Entirely corresponding findings are found in relation to the sense of urgency among employers regarding the demographic challenges, which are sought captured in the question: "To what extent is the aging of your workforce an issue in your human resource management?" It is considerably less likely that companies responding "not at all" or to a "fairly limited extent" will encourage their older employees to delay their retirement from the labor market as compared with companies answering the question "to some extent" or "high extent." In other words, the individual company being aware of questions related to population aging has practical consequences for retention and their senior policy typically refers to it. Companies in which population aging has an impact on age management policies have a more active approach to holding on to their older employees than the companies where reflections regarding population aging are absent. This result is only significant at the $10 \%$ level, as the question is very connected with the actual percentage of older employees in the company. However, the analysis shows that personnel policy that is inspired by considerations regarding population aging have an independent impact on how the company acts in relation to hanging on to its older employees.

Finally, Table 6 shows that the cognitive perceptions in the company about seniors and aging have significance for their personnel policy in practice. The analysis reveals that the company's image of older employees has an impact on its strategy for retaining their senior personnel. In companies with a positive perception of seniors-that is, where the company believes that seniors demonstrate a "willingness to learn"-we find a greater inclination to hold on to their older employees than in companies with a negative image of the willingness of older employees to learn. In companies in which they "to a high degree" or "very high degree" are of the opinion that persons over age 50 are willing to learn new things, the odds ratio is 1.94 compared with companies that do not share this positive view regarding the willingness among senior employees to learn. 


\section{Conclusion}

On the basis of the discourse concerning active aging, this article has attempted to investigate whether the aging of the population has had an impact on how companies perceive the society around them and their practice for holding on to their older employees. The paper has been guided by three research questions: How do the employers cognitively perceive seniors and the aging of the population? How are the employers responding to the prospects for shrinking workforce? What type of company is actively engaged in age management? These questions have been answered on the basis of a representative survey sent to Danish employers with ten or more employees. The survey provides answers to questions regarding the perspectives among employers and practices in relation to demographic aging, older employees, and age management.

Overall, employers hold a relatively positive view on older employees, especially with regard to their social skills, loyalty, and reliability. Furthermore, Danish employers feel a sense of urgency when it comes to a shrinking workforce, as roughly $70 \%$ of all Danish employers find that the aging of the population represents an important challenge to society as a whole. However, there are micro/macro discrepancies as to how employers believe that these challenges should be met. At the macro level, the DA has increasingly advocated for the abolition of early exit opportunities, while there is resistance to this type of thinking at the micro level. At the micro level, the individual employer is against removing the opportunities for early retirement, just as the companies are also against increasing the age of retirement. Instead, the individual employer is interested in encouraging the Danes to have more children, that work is done to attract foreign labor, and that part-time employees are encouraged to work full time.

The aging of the population plays a role in HRM policies in only $47 \%$ of the companies, and flexible working hours is the most common age management policy. Only $28.6 \%$ of Danish companies employing older workers respond that age management has been put into practice by asking a senior staff member to delay their retirement with one or more years in the course of the last 2 years. In other words, there is a rather considerable gap among the Danish companies in terms of the recognition of the problem and practical action. And there is quite a bit of evidence indicating that practical action is conditioned by structural, cognitive, and action-oriented factors alike. Large companies with welldefined personnel policy are particularly likely to make an effort in practice to keep their older employees in the labor force. Similarly, it makes a big difference if the companies view their senior staff positively. Practical action also depends on whether the company already has a written or unwritten policy for its older employees and it makes a difference whether employers feel a sense of urgency with respect to the demographic challenges.

\section{References}

Aigner, D. J. \& Cain, G. G. (1977) Statistical Theories of Discrimination in Labor Markets, Industrial and Labor Relations Review 30(2): 175-187.

Berger, J., Cohens, B. P. \& Zelditch, M. (1972) Status Characteristics and Social Interaction, American Sociological Review 37(3): 241-255.

Blöndal, S. \& Scarpetta, S. (1999) The Retirement Decision in OECD Countries, OECD Economics Department Working Papers No. 202. Paris: OECD. 
Brewster, C., Hegewisch, A., Mayne, L. \& Tregaskis, O. (1994) Methodology of the Price Waterhouse Cranfield Project. In C. Brewster \& A. Hegewisch (eds) Policy and Practice in European Human Resource Management. London: Routledge, pp. 230-245.

Brooke, L. (2003) Human Resource Costs and Benefits of Maintaining a Mature-Age Workforce, International Journal of Manpower 24(3): 260-283.

Börsch-Supan, A. (2000) Incentive Effects of Social Security on Labour Force Participation: Evidence in Germany and across Europe, Journal of Public Economics 78: 25-49.

Casey, B. (2007) The Employment of Older People: Can We Learn from Japan? In W. Loretto, S. Vickerstaff \& P. White (eds) The Future for Older Workers: New Perspectives. Bristol: Policy Press, pp. 43-63.

Correll, S. J., Benard, S. \& Paik, I. (2007) Getting a Job: Is There a Motherhood Penalty? American Journal of Sociology 112(5): 1297-1338.

van Dalen, H. P., Henkens, K., Henderikse, W. \& Schippers J. (2006) Dealing with an Ageing Labour Force: What Do European Employers Expect and Do? NIDI-report 73. The Hague: NIDI.

Dickinson, D. L. \& Oaxaca, R. L. (2006) Statistical Discrimination in Labor Markets: An Experimental Analysis. Forschungsinstitut zur Zukunft der Arbeit, IZA DP NO. 2305.

Ebbinghaus, B. (2006) Reforming Early Retirement in Europe, Japan and the USA. Oxford: Oxford University Press.

Ebbinghaus, B. (ed.) (2011) The Varieties of Pension Governance: Pension Privatization in Europe. Oxford: Oxford University Press.

European Foundation for the Improvement of Living and Working Conditions (2006) A Guide to Good Practice in Age Management. Dublin: European Foundation for the Improvement of Living and Working Conditions.

Friis, K., Jensen, P. H. \& Wégens, J. (2008) Seniorpraksis på danske arbejdspladser-baggrund, indhold og effekt (Age Management Practices in Danish Companies-Background, Content and Effects). Copenhagen: Frydenlund Academic.

Griffiths, A. (2007) Healthy Work for Older Workers: Work Design and Management Factors. In W. Loretto, S. Vickerstaff \& P. White (eds) The Future for Older Workers: New Perspectives. Bristol: Policy Press, pp. 121-137.

Gringart, E., Helmes, E. \& Speelman, C. (2008) Harnessing cognitive dissonance to promote positive attitudes toward older workers in Australia, Journal of Applied Social Psychology 38: 751-778.

Gruber, J. \& Wise, D. A. (eds) (1999) Social Security and Retirement around the World. Chicago: The National Bureau of Economic Research.

Hansen, B. G. \& Jensen, C. M. (2007) Seniorer skaber veekst (Seniors Create Growth). Copenhagen: GEU.

Hartlapp, M. \& Schmid, G. (2008) Labour Market Policy for “Active Ageing” in Europe: Extending the Options for Retirement Transitions, Journal of Social Policy 37(3): 409-431.

Henkens, K. (2005) Stereotyping Older Workers and Retirement: The Managers' Point of View, Canadian Journal on Aging 24(4): 353-366.

Hofäcker, D. (2010) Older Workers in a Globalizing World: An International Comparison of Retirement and Late-Career Patterns in Western Industrialised Countries. Cheltenham: Edward Elgar.

Ilmarinen, J. (2005) Towards a Longer Worklife! Helsinki: Finnish Institute of Occupational Health.

Immergut, E. M., Anderson, K. M. \& Schulze, I. (eds) (2007) The Handbook of West European Pension Politics. Oxford: Oxford University Press.

Institute for Employment Research (2006) Ageing and Employment-Identification of Good Practice to Increase Job Opportunities and Maintain Older Workers in Employment. http://cc.europa.eu/employment_social/emplweb/news/index/_en 
Jensen, P. H. (2004) Ageing and Work: From "Early" Exit to "Late" Exit in Denmark. In T. Maltby, B. de Vroom, M. L. Mirabile \& E. Øverbye (eds) Ageing and the Transition to Retirement. Aldershot: Ashgate, pp. 41-66.

Jensen, P. H. \& Andersen, J. G. (2011) Sverige som foregangsland? (Sweden as a Pioneering Example?) In J. G. Andersen \& P. H. Jensen (eds) Tilbagetrcekning fra arbejdsmarkedetårsager og effekter. København: Frydenlund Academic, pp. 267-280.

Jepsen, M. (2002) The Scientific Debate on Older Workers. In M. Jepsen, D. Foden \& M. Hutsebaut (eds) Active Strategies for Older Workers. Brussels: ETUI, pp. 25-50.

Kalleberg, A. L., Knoke, D., Marsden, P. \& Spaeth, J. (1996) Organizations in America: Analyzing their Structures and Human Resource Practices. London: Sage.

Kirk, H. (2007) Ældre medarbejderes ressourcer-myter og fakta (Resources of Older Employees-Myths and Facts). In Flere celdre på arbejdsmarkedet-inspiration til ledelse \& medarbejdere, Copenhagen: Ældre Forum, pp. 12-17.

Knottnerus, J. D. \& Greenstein, T. N. (1981) Status and Performance Characteristics in Social Interaction: A Theory of Status Validation, Social Psychology Quarterly 44(4): 338-349.

Larsen, M. (2006) Fastholdelse og rekruttering af celdre-Arbejdspladsens indsats (Retention and Recruitment of Older People-Efforts of the Company). Copenhagen: The Danish National Centre for Social Research (SFI).

Larsen, M. \& Miiller, M. M. (2006) Rekruttering og fastholdelse af personer over 50 ar (Recruiting and Retention of Persons Above 50 Years of Age). Copenhagen: The Danish National Centre for Social Research (SFI), Working paper 04:2006.

Lee, J. A. \& Clemons, T. (1985) Factors Affecting Employment Decisions About Older Workers, Journal of Applied Psychology 70(4): 785-788.

Luccat, D. (2005) Rekruttering og fastholdelse af seniorer (Recruiting and Retention of Seniors). Copenhagen: The Danish National Centre for Social Research (SFI), Working paper 06:2005.

Martin, C. J. (2004) Aktivering af arbejdsgivere. Aarhus: Aarhus University Press.

Møberg, R. J. (2011) Betydning af efteruddannelse for fastholdelse af ældre på arbejdsmarkedet (The Impact of Training and Re-training on the Retention of Seniors in the Labour Market). In J. G. Andersen \& P. H. Jensen (eds) Tilbagetrækning fra arbejdsmarkedetårsager og effekter. København: Frydenlund, pp. 129-135.

Oxford Research (2005) Good Practice-Fastholdelse og integration af seniorer. Copenhagen: Oxford Research.

Palier, B. (ed.) (2010) A Long Goodbye to Bismarck? The Politics of Welfare Reform in Continental Europe. Amsterdam: Amsterdam University Press.

Perry, E. L. \& Bourhis, A. C. (1998) A Closer Look at the Role of Applicant Age in Selection Decisions, Journal of Applied Social Psychology 28(18): 1670-1697.

Perry, E. L., Kulik, C. T. \& Bourhis, A. C. (1996) Moderating Effects of Personal and Contextual Factors in Age Discrimination, Journal of Applied Psychology 81(6): 628-647.

Rosen, B. \& Jerdee, T. H. (1976B) The Influence of Age Stereotypes on Managerial Decisions, Journal of Applied Psychology 61(4): 428-432.

Skirbekk, V. (2003) Age and Individual Productivity: A Literature Survey. Rostock: MaxPlanck-Institut für demografische Forschung, MPIDR working paper WP 2003-2028.

Vickerstaff, S., Cox, J. \& Keen, L. (2003) Employers and the Management of Retirement, Social Policy \& Administration 37: 271-287.

Vickerstaff, S., Loretto, W. \& White, P. (2007) The Future for Older Workers: Opportunities and Constraints. In W. Loretto, S. Vickerstaff, \& P. White (eds) The Future for Older Workers-New Perspectives. Bristol: Policy Press, pp. 203-226.

Walker, A. (1997) Combating Age Barriers in Employment-European Research Report. Dublin: European Foundation for the Improvement of Working and Living Conditions. 
Walker, A. (1998) Managing an Ageing Workforce-A Guide to Good Practice. Dublin: European Foundation.

Walker, A. (1999) Managing an Ageing Workforce. A Guide to Good Practice. Luxembourg: Office for Official Publications of the European Communities.

Walker, A. (2002) A Strategy for Active Ageing, International Social Security Review 55(1): 121-139.

Walker, A. (2005) The Emergence of Age Management in Europe, International Journal of Organisational Behaviour 10(1): 685-697.

Walker, A. (2006) Active Ageing in Employment: Its Meaning and Potential, Asia-Pacific Review 13(1): 78-93.

Walker, A. \& Taylor, P. (1999) Good Practice in the Employment of Older Workers in Europe, Ageing International 25(3): 62-79. 